Article

\title{
Probing the Surface Acidity of Supported Aluminum Bromide Catalysts
}

\author{
Md Ashraful Abedin 1,+®) Swarom Kanitkar ${ }^{1,+} \mathbb{\oplus}$, Nitin Kumar ${ }^{1}$, Zi Wang ${ }^{1}$, Kunlun Ding ${ }^{1}$, \\ Graham Hutchings ${ }^{2}$ ab and James J. Spivey ${ }^{1, *}$ \\ 1 Department of Chemical Engineering, Louisiana State University, Baton Rouge, LA 70803, USA; \\ mabedi1@lsu.edu (M.A.A.); swarom@gmail.com (S.K.); nitinkr41@gmail.com (N.K.); \\ zwang382017@outlook.com (Z.W.); kunlunding@lsu.edu (K.D.) \\ 2 Cardiff Catalysis Institute, School of Chemistry, Cardiff University, Cardiff CF10 3AT, UK; \\ hutch@cardiff.ac.uk \\ * Correspondence: jjspivey@lsu.edu; Tel.: +1-225-578-3690; Fax: +1-225-578-1476 \\ + Equal contribution for first authorship.
}

Received: 18 June 2020; Accepted: 31 July 2020; Published: 3 August 2020

check for updates

\begin{abstract}
Solid acid catalysis is an important class of reactions. The principal advantages of solid acid catalysts as compared to their corresponding fluid acids include minimal waste and ease of product separation. One type of these catalysts is based on aluminum bromide $\left(\mathrm{Al}_{2} \mathrm{Br}_{6}\right)$, which is a stronger Lewis acid than $\mathrm{Al}_{2} \mathrm{Cl}_{6}$. In this report, $\mathrm{Al}_{2} \mathrm{Br}_{6}$ is grafted on commercial mesoporous silica (CMS), SBA-15 and silica gel to create a solid catalyst similar to the silica-supported $\mathrm{Al}_{2} \mathrm{Cl}_{6}$ superacid. These supported $\mathrm{Al}_{2} \mathrm{Br}_{6}$ catalysts were characterized by $\mathrm{NH}_{3}$-Temperature Programmed Desorption (TPD), pyridine Diffuse Reflectance for Infrared Fourier Transform Spectroscopy (DRIFTS) and Magic Angle Spinning Nuclear Magnetic Resonance (MAS NMR). Formation of acid sites was confirmed and quantified with $\mathrm{NH}_{3}$-TPD. Both Lewis and Brønsted sites were observed with DRIFTS using pyridine as a probe molecule. In addition, thermal stability of acid sites was also studied using DRIFTS. ${ }^{27}$ Al MAS NMR analysis showed tetrahedral, pentahedral and octahedral co-ordination of $\mathrm{Al}$, confirming that $\mathrm{Al}_{2} \mathrm{Br}_{6}$ reacted with $-\mathrm{OH}$ groups on silica surface. Performance of these catalysts was evaluated using acid-catalyzed 1-butene isomerization. Conversion above $80 \%$ was observed at $200{ }^{\circ} \mathrm{C}$, corresponding to thermodynamic equilibrium.
\end{abstract}

Keywords: solid acid catalyst; aluminum bromide; DRIFTS; TPD; NMR; isomerization

\section{Introduction}

Acid catalysis is one of the most important area of modern catalysis and is a key step in a number of chemical processes [1]. These catalysts are utilized in solid, liquid or gaseous form. Liquid and gas phase acid catalysts often involve inorganic or mineral acids such as $\mathrm{H}_{2} \mathrm{SO}_{4}, \mathrm{HBr}$ or $\mathrm{HF}$. Although very effective, these catalysts suffer from several drawbacks-(1) difficult separation of products from the catalyst, (2) corrosiveness of the system and (3) significant quantities of waste. However, solid acids can be directly separated from the products. They can also drive the reaction towards desirable product selectivity [2]. Thus, solid acid catalysts can play a significant role in the environmentally friendly chemistry and sustainable technologies [3-6]. One important class of solid acids involve group IIIA halides-in particular aluminum halides [7-9].

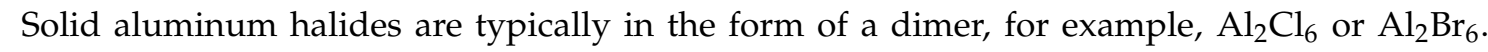
Substantial monomer concentrations are present only at temperatures at or above $300-400{ }^{\circ} \mathrm{C}$ [10]. These halides are strong solid Lewis acids and are known to catalyze various types of reactions, including Friedel Crafts alkylation, acylation [11-13], alkane isomerization and cracking [13-15] and 
polymerization [13]. These catalysts can also catalyze both the decomposition and oligomerization of the alkyl bromides at elevated temperatures [11,16-19].

Aluminum chloride, $\mathrm{Al}_{2} \mathrm{Cl}_{6}$, is a widely used acid catalyst in industry. Even though it is typically used as a solid, generation of inorganic and acidic waste through leaching remains a problem, making separation of products difficult. This has led several researchers to investigate the possibility of supporting $\mathrm{Al}_{2} \mathrm{Cl}_{6}$ on various types of solid supports like $\mathrm{SiO}_{2}$ [20-29], $\mathrm{Al}_{2} \mathrm{O}_{3}$ [30], mesoporous silica like MCM-41 [31,32], polystyrene [33-35] and so forth. These supported aluminum chloride catalysts showed high activity in various acid-catalyzed processes including alkylation [36], polymerization [26,30], isomerization [21] and Mannich synthesis [25].

Characterization of solid acid catalysts requires a range of different analytical techniques including Fourier Transform Infra-Red (FTIR) spectroscopy with pyridine as a probe molecule [21,25,26,32,37], $\mathrm{NH}_{3}$-Temperature Programmed Desorption (TPD) [32,38], solid state Magic Angle Spinning Nuclear Magnetic Resonance (MAS NMR) spectroscopy $\left({ }^{27} \mathrm{Al}[26,37,39],{ }^{1} \mathrm{H}[25],{ }^{29} \mathrm{Si}[39]\right)$, titration with various Hammett indicators (m-nitrotoluene, p-nitrotoluene etc.) [29], isomerization of n-butane to isobutane as test reaction [40].

$\mathrm{Al}_{2} \mathrm{Br}_{6}$ is another acid catalyst, which has stronger Lewis acidity compared to $\mathrm{Al}_{2} \mathrm{Cl}_{6}$ based on Fluoride Ion Affinity [41]. However, it is seldom used in the industry, primarily due to waste problems associated with $\mathrm{Al}_{2} \mathrm{Br}_{6}$. To address this problem, in principle $\mathrm{Al}_{2} \mathrm{Br}_{6}$ can be supported on a solid support to produce a strong solid acid catalyst. However, the concept of supporting $\mathrm{Al}_{2} \mathrm{Br}_{6}$ has been reported in relatively few papers [42]. One logical approach is to replace $\mathrm{Al}_{2} \mathrm{Cl}_{6}$ with $\mathrm{Al}_{2} \mathrm{Br}_{6}$ in a number of reactions [43-46]. Silica-supported $\mathrm{Al}_{2} \mathrm{Cl}_{6}$ acid catalysts can be synthesized by reacting $\mathrm{Al}_{2} \mathrm{Cl}_{6}$ with the surface hydroxyls and it is logical to determine if a similar technique could be used to support $\mathrm{Al}_{2} \mathrm{Br}_{6}$.

To our knowledge, no characterization techniques have systematically probed the strength and activity of supported $\mathrm{Al}_{2} \mathrm{Br}_{6}$ catalysts in acid-catalyzed reactions of practical interest. Hence, the objectives of our study are to (a) prepare supported $\mathrm{Al}_{2} \mathrm{Br}_{6}$ catalysts (b) characterize these supported catalysts with ${ }^{27} \mathrm{Al}$ MAS NMR to analyze $\mathrm{Al}$ co-ordination in the catalyst; (c) probe surface acidity using $\mathrm{NH}_{3}$-TPD and pyridine-DRIFTS and 1-butene isomerization; and (d) determine thermal stability of surface acid sites using high-temperature pyridine DRIFTS. $\mathrm{Al}_{2} \mathrm{Br}_{6}$ was supported on $\mathrm{SiO}_{2}$ gel and two other mesoporous silica-based supports (commercial mesoporous silica CMS, SBA-15). These three catalysts are designated as $\mathrm{ABSi}\left(\mathrm{Al}_{2} \mathrm{Br}_{6}\right.$ supported on $\left.\mathrm{SiO}_{2}\right), \mathrm{ABCS}\left(\mathrm{Al}_{2} \mathrm{Br}_{6}\right.$ supported on commercial mesoporous silica) and $\mathrm{ABSB}\left(\mathrm{Al}_{2} \mathrm{Br}_{6}\right.$ supported on SBA-15).

\section{Results and Discussion}

\subsection{BET and Pore Size Distribution}

Pore properties of the three supports used in the synthesis of the catalysts are shown in Table 1. Among the three supports, silica gel showed the highest pore volume but the lowest surface area. Mesoporous silica materials showed surface areas at around $650-750 \mathrm{~m}^{2} / \mathrm{g}$. One of the silica supports bought from vendor was MCM-41 but according to BET analysis, it had lesser surface area than the usual commercially bought MCM-41. While it was sold as MCM-41, the structural order was found to be poor and not expected for MCM-41, as so it was addressed as commercial mesoporous silica (CMS).

Table 1. Physical properties of the supports.

\begin{tabular}{ccc}
\hline Catalyst & $\mathrm{S}_{\text {BET }}\left(\mathbf{m}^{2} / \mathbf{g}\right)$ & Pore Volume $\left(\mathrm{cm}^{3} / \mathbf{g}\right)$ \\
\hline $\mathrm{SiO}_{2}$ gel & 300 & 2.00 \\
$\mathrm{CMS}$ & 638 & 1.12 \\
$\mathrm{SBA}-15$ & 735 & 0.72 \\
\hline
\end{tabular}


Figure 1 shows the Barrett-Joyner-Halenda (BJH) pore size distribution of the three supports. Silica gel (Figure 1a) has wide range of pore sizes ranging from $10 \mathrm{~nm}$ to $50 \mathrm{~nm}$, as expected. CMS and SBA-15 materials (Figure $1 \mathrm{~b}, \mathrm{c}$ ) have very small but uniform pore sizes. Pore size for CMS ranged from $1 \mathrm{~nm}$ to almost $25 \mathrm{~nm}$ although most of the pores had sizes from 2 to $5 \mathrm{~nm}$. This can be due to insufficient time for crystallization or improper crystallization conditions during commercial synthesis. Contrary to this, SBA-15 had a very narrow pore size distribution with an average pore size around $3 \mathrm{~nm}$.

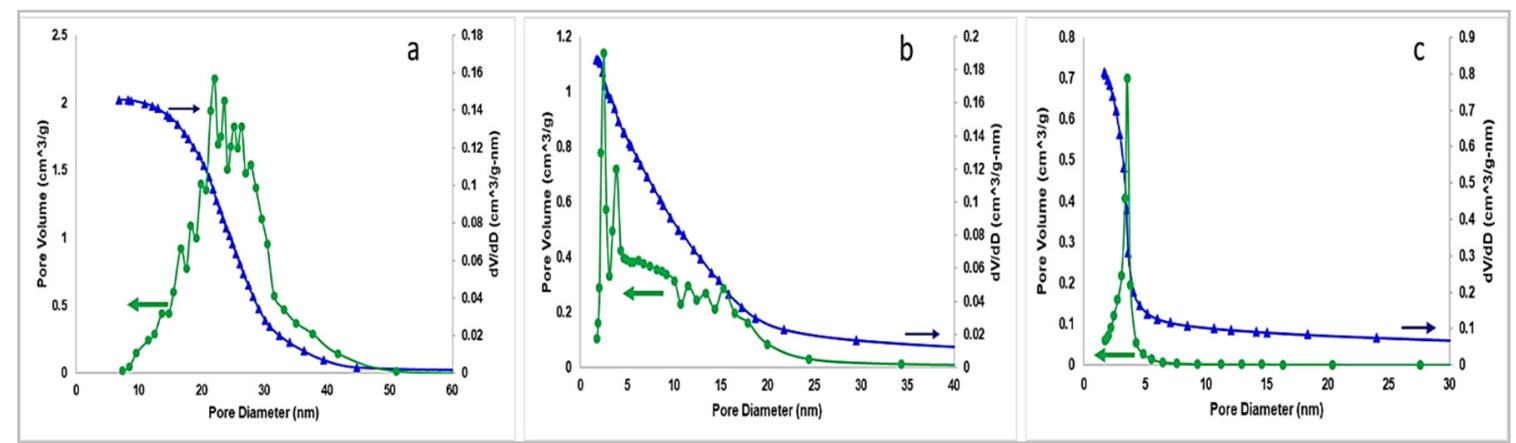

Figure 1. BJH pore size distribution for (a) Silica gel (b) commercial mesoporous silica (CMS) (c) SBA-15.

Table 2 shows the physico-chemical properties for the three catalysts. Surface area of the catalysts decreased as a result of the addition of $\mathrm{Al}_{2} \mathrm{Br}_{6}$ to the silica support, as expected.

Table 2. Physico-chemical properties of the catalysts.

\begin{tabular}{cccc}
\hline Catalyst & BET Surface Area $\left(\mathbf{m}^{\mathbf{2}} / \mathbf{g}\right)$ & Si/Al Ratio (from PIXE) & Br/Al Ratio (from XPS) \\
\hline ABSi & 260 & 18.5 & 0.99 \\
ABCS & 600 & 23.3 & 0.96 \\
ABSB & 717 & 27.1 & 1.01 \\
\hline
\end{tabular}

$\mathrm{Si} / \mathrm{Al}$ ratio was calculated using PIXE and $\mathrm{Br} / \mathrm{Al}$ ratio was calculated using XPS. Si/Al ratio was close to 20:1 for all three catalysts whereas, $\mathrm{Br} / \mathrm{Al}$ ratio was close to 1.0 for all the catalysts. This indicates that structure 1 is more likely than structure 2 (Figure 2).
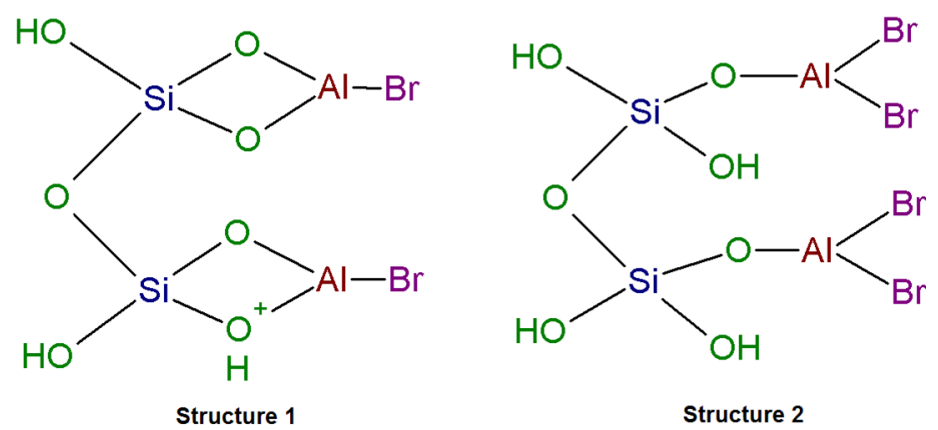

Figure 2. Possible structures of prepared catalyst.

\subsection{DRIFTS}

In conjunction with a weakly basic molecule like pyridine (proton affinity $=930 \mathrm{~kJ} / \mathrm{mol}, \mathrm{pK}_{\mathrm{b}} \sim 9$ ), FTIR can be used to clearly identify and distinguish between - Lewis (L) and Brønsted (B) acid sites. Pyridine bound to a Lewis acid site, that is, coordinately bonded pyridine, displays bands in the frequency range of around $1447-1460 \mathrm{~cm}^{-1}$ and $1620-1633 \mathrm{~cm}^{-1}$ whereas, pyridine bound to a Brønsted acid site that is, pyridinium ion displays bands in the frequency range of around $1540 \mathrm{~cm}^{-1}$ and around $1630-1640 \mathrm{~cm}^{-1}$ [47]. Also, pyridine bound in the frequency range of around 1485-1490 $\mathrm{cm}^{-1}$ 
cannot be assigned to any single acid site and is reported to contain shared acid site from both $\mathrm{L}+\mathrm{B}$ acidity $[21,25,26,32,37]$. The frequency increase of the band can be correlated to the strength and stability of the site.

The sample pretreatment temperature has a significant effect on the type of spectra after pyridine adsorption. Especially if supported, $\mathrm{AlX}_{3}$ samples are pretreated above $150-200{ }^{\circ} \mathrm{C}$ before pyridine adsorption, loss in Brønsted acid sites could be observed through loss of OH groups via dehydration $[26,32,36,37]$.

Silica $\left(\mathrm{SiO}_{2}\right)$ is very weakly acidic. So it was expected not to show any strong pyridine adsorption, which is confirmed for all the three supports. All the three supports only showed two principal peaks at $1447 \mathrm{~cm}^{-1}$ and $1599 \mathrm{~cm}^{-1}$ that most likely correspond to hydrogen-bonded pyridine that is, $-\mathrm{OH}$ bound pyridine on the silica surface and these peaks also disappear upon treatment of the catalysts at higher temperatures. No significant peak could be observed when samples were heated to temperatures more than $200{ }^{\circ} \mathrm{C}$ (Supplementary Data). Contrary to this, all three catalysts showed peaks corresponding to $\mathrm{L}, \mathrm{L}+\mathrm{B}$ and $\mathrm{B}$ acid sites as could be seen from Figure 3. Also, all of the catalysts showed peaks corresponding to hydrogen bonded pyridine (particularly $1600-1620 \mathrm{~cm}^{-1}$ ) that overlapped with a Lewis acid site peak $\left(1620-1630 \mathrm{~cm}^{-1}\right)$ up to $150^{\circ} \mathrm{C}$. However, above $150{ }^{\circ} \mathrm{C}$, mostly L site peaks could be observed.

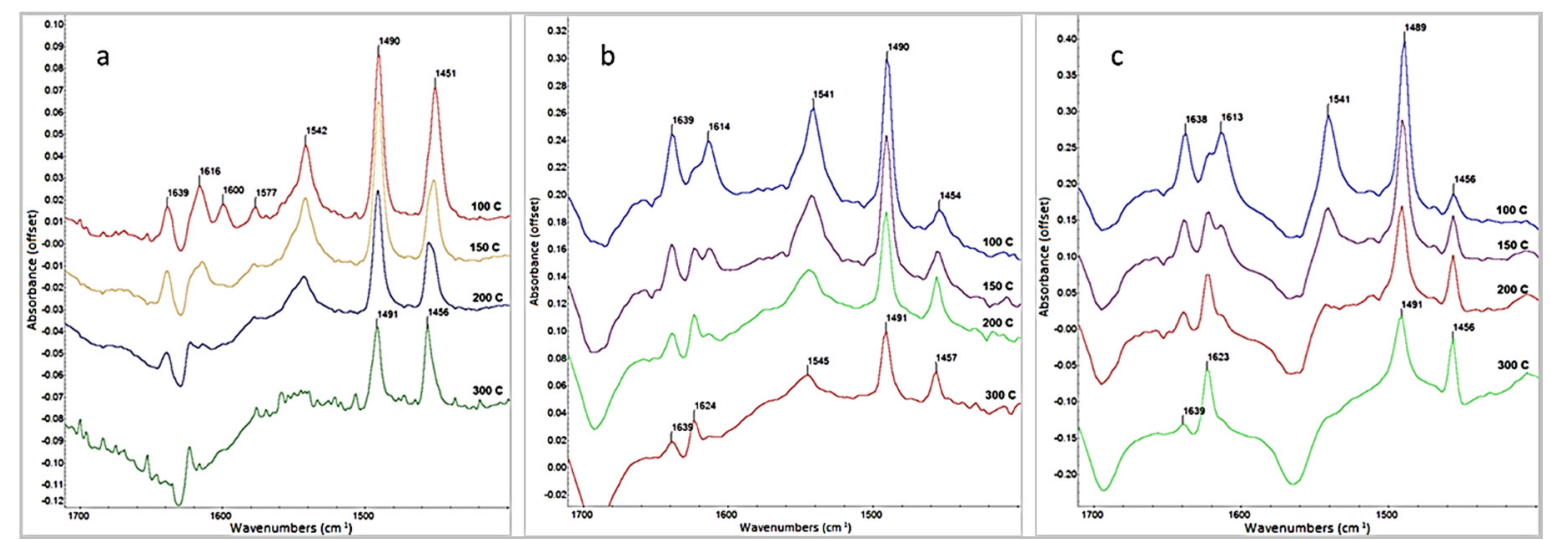

Figure 3. DRIFTS spectra for (a) ABSi (b) ABCS and (c) ABSB after pyridine treatment at various temperatures.

Figure 3 shows DRIFTS spectra for the three supported catalysts at various temperatures after adsorption of pyridine. Figure 3a shows DRIFTS spectra for ABSi catalyst at various temperatures after adsorption of pyridine. As expected, the spectra follow the similar trend of other mesoporous silica supported catalysts, ABCS and ABSB. However, when the ABSi peak at $1450 \mathrm{~cm}^{-1}$ is deconvoluted, it is found to be a combination of two peaks, one hydrogen bound pyridine $\left(1447 \mathrm{~cm}^{-1}\right)$ and the other a Lewis acid site peak $\left(1454 \mathrm{~cm}^{-1}\right)$. There is a single peak only after treatment at $300{ }^{\circ} \mathrm{C}$ which probably corresponds to a strong Lewis acid site $\left(\sim 1456 \mathrm{~cm}^{-1}\right)$. This is expected as hydrogen bound pyridine would desorb at this temperature of $300^{\circ} \mathrm{C}$.

For ABCS, Figure $3 b$ shows three types of acid sites-(L) $\sim 1454 \mathrm{~cm}^{-1}$ and $1625 \mathrm{~cm}^{-1}$, $(\mathrm{L}+\mathrm{B}) \sim 1490 \mathrm{~cm}^{-1}$, (B) $\sim 1541 \mathrm{~cm}^{-1}$ and $\sim 1638 \mathrm{~cm}^{-1}$. Up to $150{ }^{\circ} \mathrm{C}$, one can clearly see bands for pyridine coordinated with three different types of acid sites-(L) $\sim 1450 \mathrm{~cm}^{-1}$ and $1625 \mathrm{~cm}^{-1}$, $(\mathrm{L}+\mathrm{B}) \sim 1486 \mathrm{~cm}^{-1}$, (B) $\sim 1536 \mathrm{~cm}^{-1}$ and $\sim 1636 \mathrm{~cm}^{-1}$.

In the case of ABSB, no peaks corresponding to Brønsted acid sites at temperatures $\geq 200{ }^{\circ} \mathrm{C}$ can be seen from Figure 3c. However, one interesting feature for the ABSB catalyst is that, when treated at higher temperatures that is, from $100{ }^{\circ} \mathrm{C}$ to $300{ }^{\circ} \mathrm{C}$, there is a decrease in the intensity of peaks corresponding to Brønsted acid sites, whereas, the intensity of peaks corresponding to Lewis acid sites increased. The increase in Lewis acid sites could be due to rearrangement of Brønsted acid sites upon loss of $-\mathrm{OH}$ groups at higher temperatures [48]. 
It was observed from pyridine DRIFTS on the three catalysts that, at the reaction temperature of $200{ }^{\circ} \mathrm{C}$, the acid sites generated after Aluminum bromide deposition on different supports are mostly stable, which is true for both the Brønsted and Lewis sites.

\subsection{Ammonia-TPD}

$\mathrm{NH}_{3}$-TPD provides a quantitative probe of the overall acidity of a catalyst. Thus it can be used to characterize the supported $\mathrm{Al}_{2} \mathrm{Br}_{6}$ catalysts of interest here. Figure 4 shows MS signals for desorbed ammonia from all three catalysts along with the three supports. A small peak at $\sim 150{ }^{\circ} \mathrm{C}$ is observed for pure silica, which is believed to be a weak acid site. For the base CMS, almost no acidity was observed except for a very small peak at around $140{ }^{\circ} \mathrm{C}$ that corresponds to the weak acid sites (most likely due to hydroxyl groups). SBA-15 did not show any significant peak.

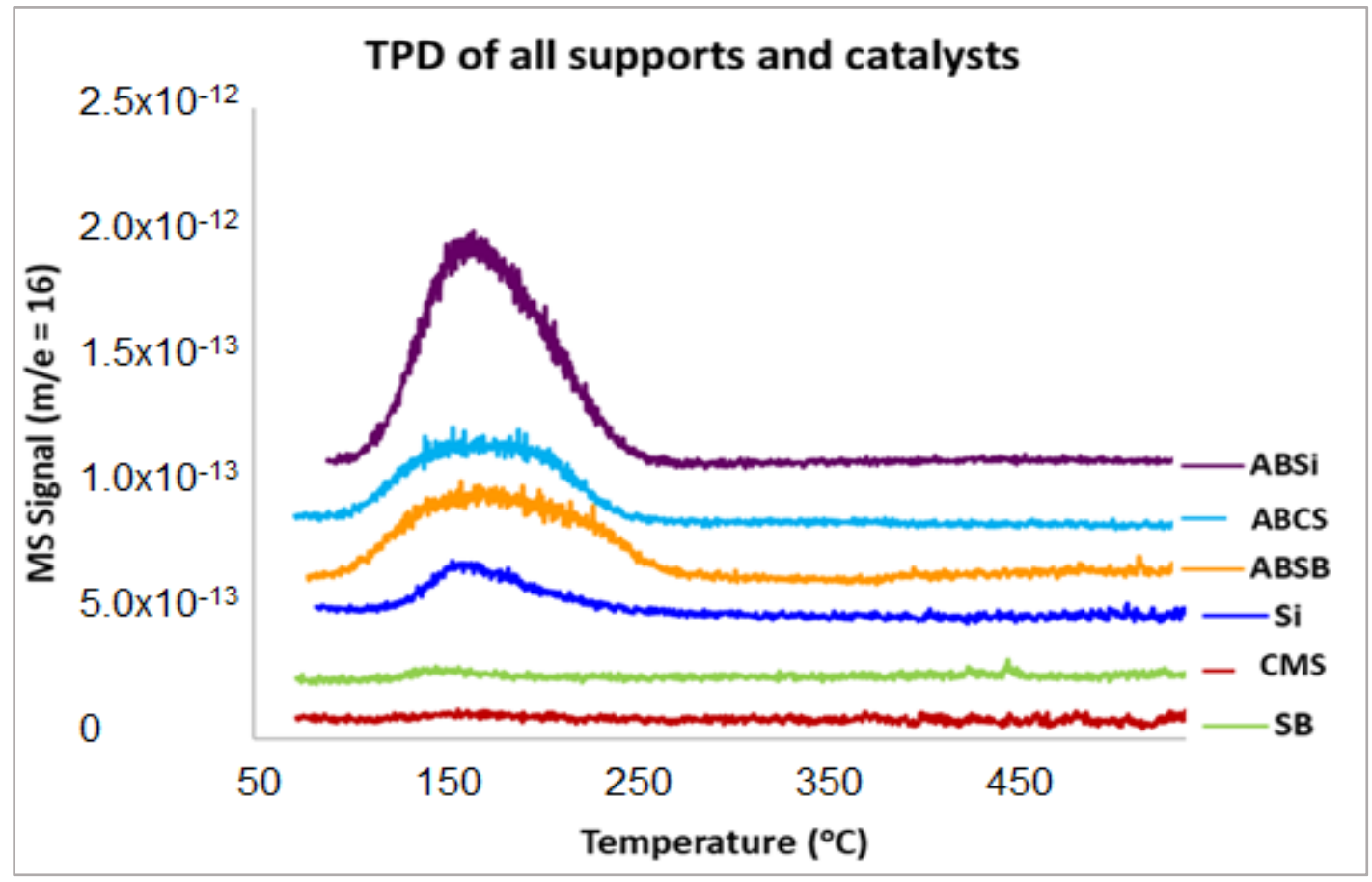

Figure 4. Ammonia Temperature Programmed Desorption (TPD) for supports and various catalysts.

All three catalysts showed two peaks upon deconvolution (see Supplementary Data), indicating two types of acid sites. These two sites correspond to weak-to-medium strength acid sites.

Table 3 shows the peak positions for ABCS to be higher than to the other two catalysts, which refers to the presence of stronger acid sites. For ABCS catalyst, peaks at around $154{ }^{\circ} \mathrm{C}, 197{ }^{\circ} \mathrm{C}$ could be observed upon deconvolution. The first peak observed corresponds to weak acid site-mainly hydroxyl groups and the peak at $197^{\circ} \mathrm{C}$ can be attributed to moderate acid sites $[36,49,50]$. For peak temperatures above $300{ }^{\circ} \mathrm{C}$, insignificant ammonia desorption could be observed from MS signals from Figure 4 , indicating the absence of very strong acid sites.

Table 3. De-convoluted peak positions for $\mathrm{NH}_{3}$-TPD curves.

\begin{tabular}{ccc}
\hline Catalyst & Peak $\mathbf{1}\left({ }^{\circ} \mathbf{C}\right)$ & Peak 2 $\left({ }^{\circ} \mathbf{C}\right)$ \\
\hline ABSi & 144 & 179 \\
ABCS & 154 & 197 \\
ABSB & 143 & 195 \\
\hline
\end{tabular}

In terms of the total number of acid sites, ABSB showed the highest amount of $\mathrm{NH}_{3}$ desorbed (as measured by concentration) as can be seen from Table 4 . This could have been due to higher dispersion 
observed for SBA-15 during BET analysis [51]. Although experimentally not verified, it is also possible that some of the $\mathrm{Al}$ is located more on the surface than in the bulk. This can also lead to the observed differences. The differences in peak positions could also be because of different types of site formation on the silica surfaces. Also, SBA- 15 has a stronger interaction with $\mathrm{H}_{2} \mathrm{O}$ molecules (in turn -OH groups) inside the pore, as compared to CMS, which might have been the cause of the difference [52]. Further, surface structures found on different silica surfaces result in different surface reactivity and also in different binding strengths. The density of silanol groups on the silica surfaces can also vary leading into different types of acid sites [53]. All of these factors could lead to the observed differences in the types of acidities and peak positions.

Table 4. Summary of $\mathrm{NH}_{3}$-TPD results.

\begin{tabular}{cccc}
\hline Catalyst & ABSi & ABCS & ABSB \\
\hline Si/Al ratio & 18.5 & 23.3 & 27.1 \\
Ammonia adsorbed $(\mu \mathrm{mol} / \mathrm{g})$ & 606 & 381 & 622 \\
$\begin{array}{c}\text { Ammonia adsorbed on corresponding plain support } \\
(\mu \mathrm{mol} / \mathrm{g})\end{array}$ & $129\left(\mathrm{SiO}_{2}\right)$ & $10.6(\mathrm{CMS})$ & $78.9(\mathrm{SBA}-15)$ \\
$\mathrm{Ammonia}$ adsorption coming from $\mathrm{Al}$ insertion & & & 543 \\
$(\mu \mathrm{mol} / \mathrm{g})$ & 476 & 371 & $0.62 \mathrm{mmol}$ \\
$\mathrm{Al}$ content (based on $\left.16.64 \mathrm{mmol} \mathrm{SiO}_{2} / \mathrm{g}\right)$ & $0.90 \mathrm{mmol}$ & $0.71 \mathrm{mmol}$ & $0.87-1.00$ \\
$\mathrm{NH}_{3} / \mathrm{Al}$ & $0.54-0.67$ & $0.52-0.53$ & \\
\hline
\end{tabular}

\section{4. ${ }^{27}$ Al MAS NMR}

Figure 5 shows the MAS ${ }^{27} \mathrm{Al}$ NMR spectra for all the three catalysts. These catalysts did show similar shifts for ${ }^{27} \mathrm{Al} \mathrm{NMR}$, indicating that pore structure did not influence the co-ordination type of $\mathrm{Al}$ and similar type of hydroxyl groups that were available for reaction. For these catalysts, three peaks could be seen, which are at NMR shifts of around $2 \mathrm{ppm}, 30 \mathrm{ppm}$ and $50 \mathrm{ppm}$. These could correspond to 6 co-ordinated, 5 co-ordinated and 4 co-ordinated aluminum [32,36,39]. The 6 co-ordinated aluminum peaks might have largely been due to exposure to moisture while loading of the rotor (carried out in presence of air). This similar effect was seen in the $\mathrm{Al}_{2} \mathrm{Cl}_{6}$ grafted silica samples when they were loaded into the rotor without Teflon tape and were exposed to some amount of moisture [39]. 5 co-ordinated aluminum could be co-ordinated with 2- $\mathrm{Br}$ atoms, $2-\mathrm{OH}$ groups (silanol groups) and $1 \mathrm{O}$ atom and would most likely be a Brønsted site. The 4 co-ordinated aluminum could be co-ordinated with 2-Br atoms, $1-\mathrm{OH}$ group (silanol group) and $1 \mathrm{O}$ atom and would most likely be a Lewis acid site (being electron deficient) [36]. Also it is said that 5 co-ordinated site arises through interaction of $\mathrm{AlX}_{3}$ with a geminal silanol group and 4 co-ordinated through interaction with 2 silanol groups [32].

Based on the results from ${ }^{27} \mathrm{Al} \mathrm{NMR}$, the following structures (Figure 6) are consistent with the results shown here for silica supported $\mathrm{Al}_{2} \mathrm{Br}_{6}$ catalysts and are similar to the supported $\mathrm{Al}_{2} \mathrm{Cl}_{6}$ catalysts [39].

A difference in Al: Br ratio is observed for NMR bulk analysis and XPS surface analysis. Based on NMR, it is estimated that Al: Br ratio of 1:2 or 1:3 can be found in catalytic bulk, whereas XPS suggests an Al: Br ratio of 1:1 to be present on catalytic surface. This can be due to a possible leaching of $\mathrm{Al}$ from bulk to surface area.

\subsection{Double Bond Isomerization of 1-Butene}

Reaction data at $100{ }^{\circ} \mathrm{C}$ and $200{ }^{\circ} \mathrm{C}$ and at different weight hour space velocity (WHSV) are recorded in Figures 7 and 8. At room temperature, none of the catalysts showed any appreciable activity. For the space velocity of $66 \mathrm{~L} /$ gcat-hr (based on total inlet flow), at $100{ }^{\circ} \mathrm{C}$, conversions were very low $(<5 \%)$ for double bond isomerization of 1-butene (Figure 7). However, at $200{ }^{\circ} \mathrm{C}$, all the three catalysts showed strong activity in isomerization of 1-butene to 2-butene (both cis and trans). ABCS especially showed conversion values of around $84 \%$ with trans selectivity around $40 \%$ and 
cis-2-butene to be around $60 \%$. The other two catalysts showed roughly similar values, $22 \%$ conversion and product selectivities around $30 \%$ and $70 \%$ for trans and cis-2-butene respectively.

a

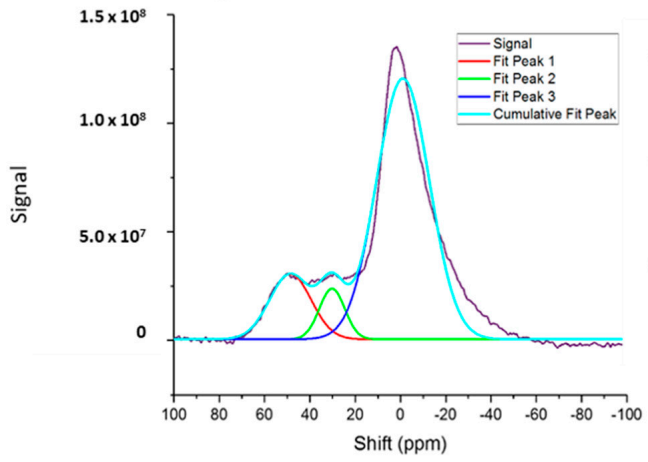

C $\mathrm{b}$

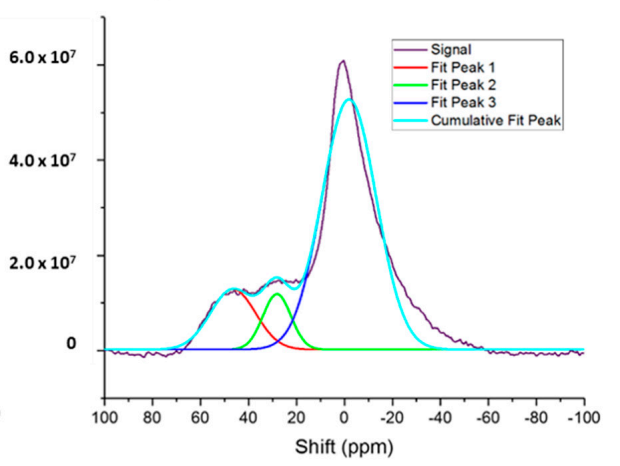

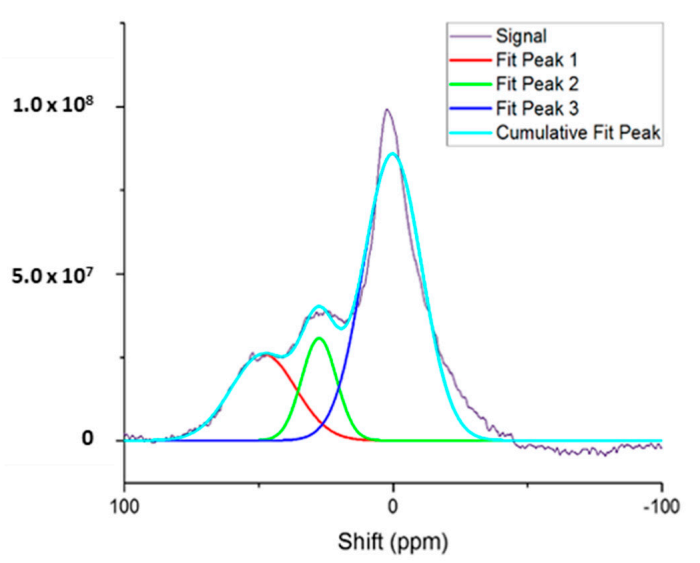

Figure 5. ${ }^{27} \mathrm{Al}$ Nuclear Magnetic Resonance (NMR) for the three catalysts (a) ABSi (b) ABCS (c) ABSB.

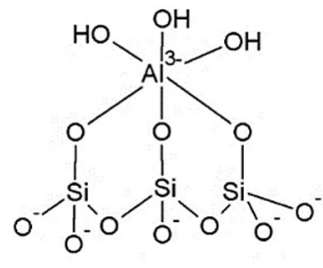

Octahedral

(6 co-ordinated)<smiles>[O-][Si]1([O-])O[Si]([O-])(Br)[OH+][Ge](Br)(Br)O1</smiles>

Tetrahedral

(4 co-ordinated)

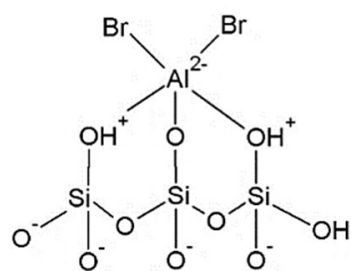

Pentahedral

(5 co-ordinated)<smiles></smiles>

Tetrahedral

(4 co-ordinated)<smiles>O[Si]1(O)O[Ge](O)(O)O[Te](Br)(Br)([Al](Br)(Br)Br)O1</smiles>

Pentahedral

(5 co-ordinated)

Figure 6. Possible structures of silica supported $\mathrm{Al}_{2} \mathrm{Br}_{6}$ catalysts. 


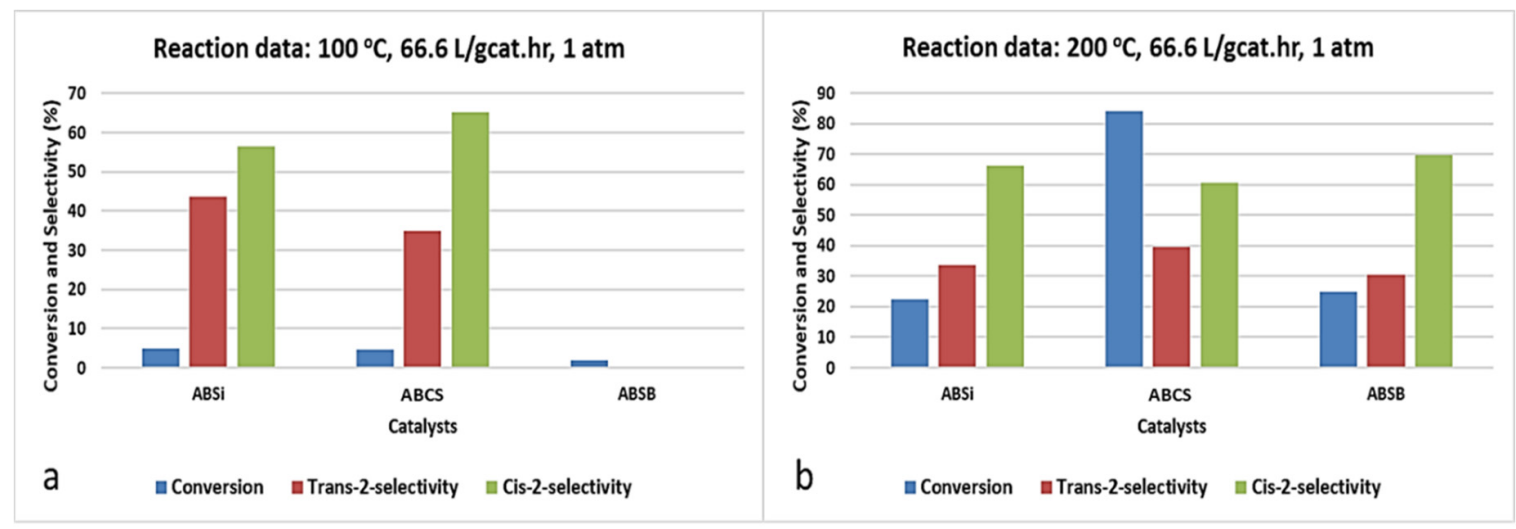

Figure 7. Reaction data for the isomerization of 1-butene at (a) $100{ }^{\circ} \mathrm{C}$ (b) $200{ }^{\circ} \mathrm{C}, 66.6 \mathrm{~L} / \mathrm{gcat}-\mathrm{hr}, 1 \mathrm{~atm}$.

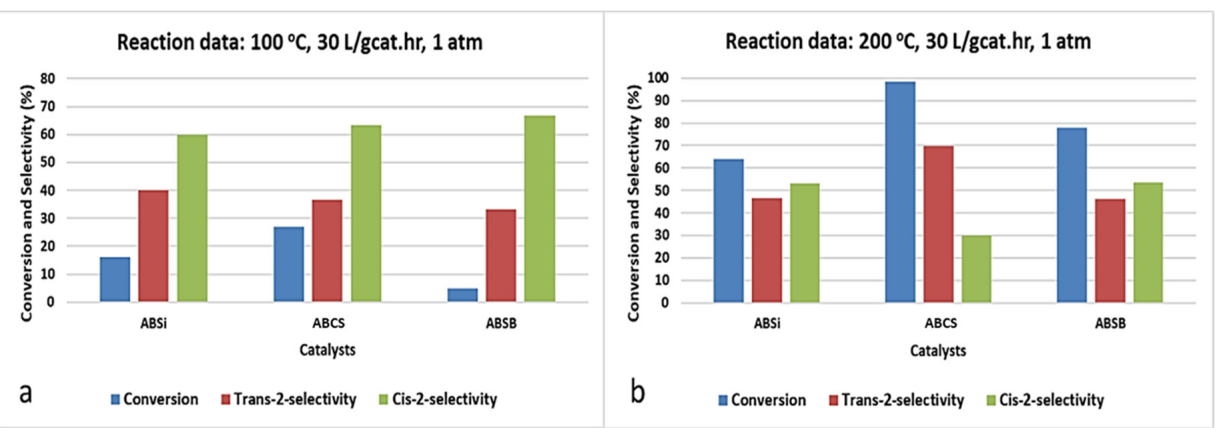

Figure 8. Reaction data for the isomerization of 1-butene at (a) $100{ }^{\circ} \mathrm{C}$ (b) $200{ }^{\circ} \mathrm{C}, 30 \mathrm{~L} / \mathrm{gcat}-\mathrm{hr}, 1 \mathrm{~atm}$.

When the space velocity was decreased to $30 \mathrm{~L} /$ gcat-h (based on total inlet flow), the conversion of 1-butene increased significantly (Figure 8), with higher selectivity to Cis-2-butene at $100^{\circ} \mathrm{C}$. However, at $200^{\circ} \mathrm{C}$, conversion as well as Tran-selectivity increased. ABCS showed excellent results at $200{ }^{\circ} \mathrm{C}$ with conversion reaching as high as $98 \%$ with a higher selectivity towards Trans-2-butene. This standout performance of $\mathrm{ABCS}$ with comparison to the other catalysts can be attributed to the presence of slightly stronger acid sites (both Lewis and Brønsted) at $200{ }^{\circ} \mathrm{C}$. Although, $\mathrm{NH}_{3}-\mathrm{TPD}$ showed that $\mathrm{ABCS}$ had least ammonia adsorption, it is possible that $\mathrm{ABCS}$ had stronger but fewer acid sites on the surface compared to other two catalysts.

The ratio of cis/trans isomers was typically greater than one at higher space velocities (and therefore at lower conversions). At lower space velocities, the cis/trans ratio decreased to the more thermodynamically stable ratio.

At reaction temperatures above $200{ }^{\circ} \mathrm{C}$, trace levels of some high carbon-number products like $\mathrm{C}_{5}$ and $\mathrm{C}_{6}$ were also observed (not shown) that could have been due to oligomerization. This suggests the possibility of the presence of higher carbon number products that might form coke on the catalyst surface. Because $200{ }^{\circ} \mathrm{C}$ is too low to induce cracking, no other significant side-products were observed. These results confirm the presence of weak to moderate acid sites on the surface of these catalysts that are selectively able to isomerize 1-butene into 2-butene.

In order to verify the stability of the best performing catalyst-ABCS, a longer run for $24 \mathrm{~h}$ was carried out at $200{ }^{\circ} \mathrm{C}$ (Figure 9). Very high and stable conversion of $\sim 95 \%$ was observed without any apparent deactivation. Selectivities towards trans and cis stayed consistent at around $46 \%$ and $54 \%$, respectively. 


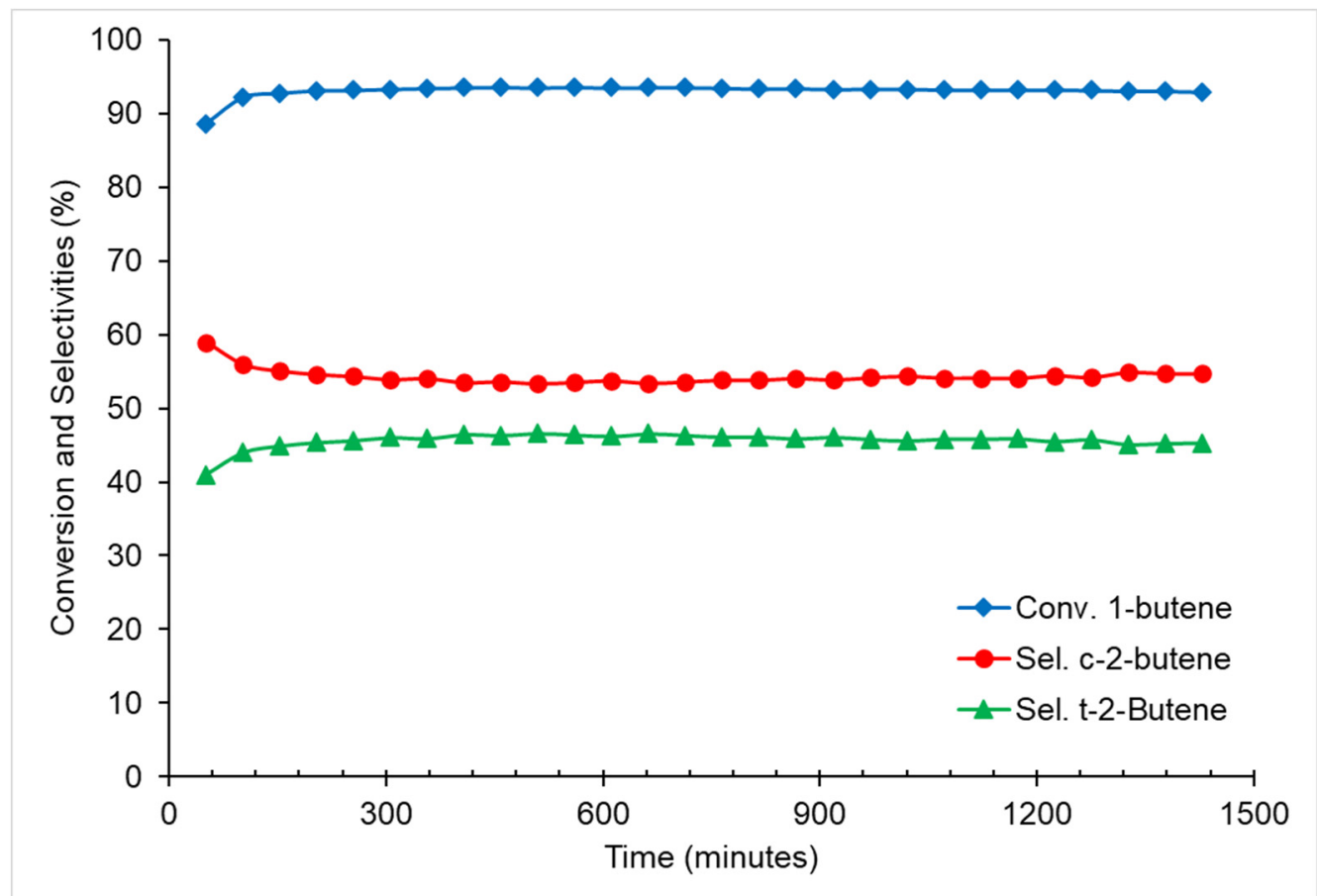

Figure 9. Time on stream for 1-butene over ABCS catalyst $\left(200{ }^{\circ} \mathrm{C}, 66.6 \mathrm{~L} / \mathrm{gcat}-\mathrm{hr}, 1 \mathrm{~atm}\right)$.

\section{Materials and Methods}

\subsection{Materials}

$\mathrm{Al}_{2} \mathrm{Br}_{6}$ (anhydrous, 98\%) was purchased from Alfa Aesar Inc., Ward Hill, MO, USA. SiO 2 gel was purchased from PQ Corporation, Pineville, LA, USA. Mesoporous silica materials (MCM-41 and SBA-15) were purchased from Bonding Chemical, Katy, TX, USA. Due to low surface area and poor pore structure observed during BET, MCM-41 was later renamed as commercial mesoporous silica or CMS. Toluene (Anhydrous, 99.8+\%) was purchased from Sigma Aldrich Inc., St. Louis, MO, USA. Vapor phase pyridine in Argon (UHP grade) was purchased from Praxair Inc., Danbury, CT, USA. $\mathrm{NH}_{3} / \mathrm{He}$ gas mixture and 1-butene (500 ppm) in Argon were purchased from Airgas Inc., Radnor, PA, USA.

\subsection{BET and Pore Size Distribution}

BET and pore size distribution of the supports and catalyst materials were carried out using Altamira-200 (Altamira Technologies Corporation, McLean, VA, USA) and Micromeritics ASAP 2020 Plus instrument (Micromeritics Instrument Corporation, Norcross, GA, USA) respectively. In a typical degassing sequence, catalysts were evacuated in $15 \mu \mathrm{m} \mathrm{Hg}$ at $350{ }^{\circ} \mathrm{C}$ for $3 \mathrm{~h}$ and were subsequently cooled to room temperature before actual pore size distribution measurements were done. For calculations, Desorption branch of isotherms and Broekhoff De Boer curve thickness equation was used.

\subsection{Catalyst Preparation}

Three different supported $\mathrm{Al}_{2} \mathrm{Br}_{6}$ catalysts were prepared following the literature methods for supported $\mathrm{Al}_{2} \mathrm{Cl}_{6}$ catalysts [23,36,37], naming $\mathrm{ABSi}\left(\mathrm{Al}_{2} \mathrm{Br}_{6}\right.$ supported on $\left.\mathrm{SiO}_{2}\right), \mathrm{ABCS}\left(\mathrm{Al}_{2} \mathrm{Br}_{6}\right.$ supported on CMS) and $\mathrm{ABSB}\left(\mathrm{Al}_{2} \mathrm{Br}_{6}\right.$ supported on SBA-15). In a typical preparation, $\mathrm{Al}_{2} \mathrm{Br}_{6}(2 \mathrm{mmol})$ are mixed with anhydrous toluene $(50 \mathrm{~mL})$ and the mixture was refluxed for $2 \mathrm{~h}$, following which pre-dried support $\left(5 \mathrm{~g}\right.$, dried at $300{ }^{\circ} \mathrm{C}$ for $16 \mathrm{~h}$ and further vacuum dried at room temperature for $6 \mathrm{~h}$ ) is added and then refluxed for $3 \mathrm{~h}$, followed by cooling to ambient temperature and filtered using 
vacuum pump and finally dried for $16 \mathrm{~h}$ under vacuum. The dried catalyst powder was then weighed and stored under an inert atmosphere for further use. $\mathrm{Al}_{2} \mathrm{Br}_{6}$ being moisture sensitive, all the materials were handled under inert atmosphere using a glovebox and Schlenk flasks.

\subsection{Elemental Analysis}

Ratio of $\mathrm{Si} / \mathrm{Al}$ from the elemental content was calculated using PIXE (Proton Induced X-ray Emission) technique at Elemental Analysis Inc. (EAI), Lexington, KY, USA. Because Bromine would be incorporated at the surface rather than in the bulk, the ratio of $\mathrm{Br} / \mathrm{Al}$ was calculated using Kratos AXIS 165 XPS instrument at the LSU Shared Instrumentation Facility (SIF) (Louisiana State University, Baton Rouge, LA, USA).

\subsection{DRIFTS}

Pyridine was used as a probe molecule in Diffuse Reflectance Infrared Fourier Transform Spectroscopy (DRIFTS) experiment. A Thermo Scientific Nicolet 6700 FTIR (Thermo Fisher Scientific, Waltham, MA, USA) equipped with Harrick Praying Mantis reaction cell fitted with KBr windows was used to carry out the experiment. IR cell was loaded with the catalyst sample inside the glovebox to avoid air and moisture exposure. Helium was introduced in the cell, followed by pretreatment at $100{ }^{\circ} \mathrm{C}$ for $30 \mathrm{~min}$ to clean the surface from adsorbed impurities. Sample was cooled down to $25^{\circ} \mathrm{C}$ after pretreatment and a background spectrum was recorded with a spectral resolution of $4 \mathrm{~cm}^{-1}$ in region going from $4000-650 \mathrm{~cm}^{-1}$. Catalyst was saturated with gaseous pyridine for $180 \mathrm{~min}$ at $25^{\circ} \mathrm{C}$. He was later introduced again in the post saturation step to remove physiosorbed pyridine from the catalyst surface as well as the cell chamber. Sample was then treated at $100{ }^{\circ} \mathrm{C}$ for $10 \mathrm{~min}$ and cooled back to room temperature and the actual spectrum was recorded. Similar spectra were recorded at room temperature after $10 \mathrm{~min}$. Treatments were done at $150{ }^{\circ} \mathrm{C}, 200{ }^{\circ} \mathrm{C}$ and $300{ }^{\circ} \mathrm{C}$ to investigate the thermal stability of the acid sites on catalysts.

\subsection{Ammonia-TPD}

The Altamira AMI-200 reactor system in conjunction with Ametek Mass Spectrometer (Ametek, Berwyn, PA, USA) was used to run Ammonia-TPD. $25 \mathrm{mg}$ of the prepared catalyst was loaded on a quartz tube reactor, followed by pretreatment. The temperature was ramped up to $100{ }^{\circ} \mathrm{C}$ under $30 \mathrm{sccm}$ of He for $30 \mathrm{~min}$ to get rid of any weakly adsorbed particles. The sample was then cooled down to $50{ }^{\circ} \mathrm{C}$ under $\mathrm{He}$, before introducing $40 \mathrm{sccm}$ of $5 \% \mathrm{NH}_{3} / \mathrm{He}$ to start $\mathrm{NH}_{3}$ adsorption process for $60 \mathrm{~min}$. $25 \mathrm{sccm}$ of He was flown for $40 \mathrm{~min}$ to remove any residual ammonia. TCD detector was later turned on and the temperature was ramped up at $10{ }^{\circ} \mathrm{C} / \mathrm{min}$. from $50{ }^{\circ} \mathrm{C}$ to $500{ }^{\circ} \mathrm{C}$. Based on the combination of Ammonia ( $/ \mathrm{e}=16$ ) signals from MS and the signal from TCD, amounts of ammonia desorbed and peak positions were calculated to quantify the corresponding acid sites available on the catalyst.

\subsection{MAS NMR Measurements}

Solid state ${ }^{27} \mathrm{Al}$ MAS NMR spectra for all three catalysts were recorded at $104.23 \mathrm{MHz}$ in a Bruker AV-400 spectrometer (Bruker, Billerica, MA, USA) equipped with a $4 \mathrm{~mm}$ probe and at a MAS speed of $12 \mathrm{kHz}$. Recovery time of $0.1 \mathrm{~s}$ was allowed between the $0.55 \mu$ s pulses that correspond to $10^{\circ}$ flip angle and 75,000 scans were recorded for each sample. Chemical shifts (ppm) corresponding to ${ }^{27} \mathrm{Al}$ were referenced to $0.5 \mathrm{M}$ solution of $\mathrm{Al}\left(\mathrm{NO}_{3}\right)_{3}$ in water.

\subsection{Double Bond Isomerization}

Positional isomerization reaction of 1-butene to 2-butene (cis, trans) can be catalyzed by both acids and bases. In order to test the activity of the acid sites on the $\mathrm{AlBr}_{3}$ supported catalysts, double bond isomerization of 1-butene was carried out in an Altamira AMI 200HP reactor system 
(Altamira Technologies Corporation, McLean, VA, USA) equipped with a glass lined SS tube. In a typical experiment, reactor tube would be loaded with $0.1 \mathrm{~g}$ of catalyst and small quantities of 1-butene (500 ppm) in Argon would be passed over the catalyst bed. Reaction products were analyzed downstream using Shimadzu GC2014 (FID) equipped with Restek RT-Q-Bond column ( $30 \mathrm{~m} \times 0.53 \mathrm{~mm}$ $\times 20 \mu \mathrm{m})$.

\section{Conclusions}

This work includes the study of $\mathrm{Si} / \mathrm{Al}$ oxide based Aluminum Bromide solid acid catalysts based on their surface acidity. PIXE analysis showed that the Si/Al ratio was close to 20:1 for all the catalysts. XPS probing of the surface of the catalysts suggested a 1:1 $\mathrm{Al}: \mathrm{Br}$ ratio, indicating that $\mathrm{Al}$ is most probably bonded to $2 \mathrm{O}$ atoms from silica and 1 bromine. ABSB catalyst showed highest acidity qualitatively from DRIFTS, in quantitative agreement with $\mathrm{NH}_{3}$-TPD results. Although ABCS showed lower acidity, DRIFTS showed that it had stronger acid sites but fewer of them. This is consistent with the observed strong activity of ABCS in double bond isomerization of 1-butene to 2-butene. High temperature DRIFTS experiments showed both Lewis and Brønsted stable acid sites up to $200{ }^{\circ} \mathrm{C}$. Above $200{ }^{\circ} \mathrm{C}$, primarily only Lewis acid sites were present. $\mathrm{NH}_{3}$-TPD indicated the presence of weaker acid sites and did not show the presence of strong acid sites $\left(>300^{\circ} \mathrm{C}\right) \cdot{ }^{27} \mathrm{Al}$ MAS NMR results showed primarily 4,5 and 6 co-ordinated aluminum in the case of these supported catalysts confirming that - $\mathrm{Br}$ from $\mathrm{Al}_{2} \mathrm{Br}_{6}$ reacted with $-\mathrm{OH}$ groups on silica surface and further confirming that $\mathrm{Al}_{2} \mathrm{Br}_{6}$ are bound to these supports. Al doped CMS was found to be the most active catalyst for the isomerization of 1-butene, with thermodynamically stable cis/trans ratio. Conversion of 1-butene towards 2-butene reached the highest at $98 \%$ in presence of ABCS when the temperature was increased and the space velocity was decreased.

Supplementary Materials: The following are available online at http://www.mdpi.com/2073-4344/10/8/869/s1. Figure S1. DRIFTS spectra for MCM-41 after pyridine treatment at various temperatures. Figure S2. DRIFTS spectra for SBA-15 after pyridine desorption at various temperatures. Figure S3. DRIFTS spectra for Silica gel after treatment at various temperatures. Figure S4. Deconvoluted MS peaks for ABM4 catalyst. Figure S5. Deconvoluted MS peaks for ABSB catalyst. Figure S6. Deconvoluted MS peaks for ABSi catalyst. Figure S7. Isotherm linear plot for Silica Gel. Figure S8. Isotherm linear plot for MCM-41. Figure S9. Isotherm linear plot for SBA-15. Figure S10. Confirmation of pore diameter for MCM-41 from manufacturer website. Figure S11. Confirmation of pore diameter for SBA-15 from manufacturer website.

Author Contributions: Conceptualization, S.K., K.D. and J.J.S.; Methodology, S.K., M.A.A. and K.D.; Validation, G.H. and J.J.S.; Formal Analysis, M.A.A. and S.K.; Investigation, M.A.A., S.K. and N.K.; Resources; J.J.S. and K.D.; Data Curation, S.K. and M.A.A.; Writing; M.A.A. and S.K.; Writing-Original Draft Preparation, S.K., Z.W., N.K. and M.A.A.; Writing-Review and Editing; M.A.A. and S.K.; Visualization; S.K. and M.A.A.; Supervision, J.J.S., K.D. and G.H.; Project Administration, J.J.S.; Funding Acquisition, J.J.S. All authors have read and agreed to the published version of the manuscript.

Funding: Authors would like to thank Chevron and NSF for the financial support for this project through Chevron Innovation Research Fund and NSF EAGER grant (Award \# 1644895) respectively.

Acknowledgments: The authors would also like to thank Thomas Weldeghiorghis of the LSU NMR facility for help in carrying out ${ }^{27} \mathrm{Al}$ MAS NMR experiments. Authors finally would like to thank Marshall Moulis and George Stanley of LSU Chemistry for help in the preparation of the catalysts.

Conflicts of Interest: The authors declare no conflict of interest.

\section{References}

1. Arata, K.; Matsuhashi, H. Solid Superacids; Nova Science Publishers: Hauppauge, NY, USA, 2011.

2. Abedin, M.A.; Kanitkar, S.; Bhattar, S.; Spivey, J.J. Methane dehydroaromatization using Mo supported on sulfated zirconia catalyst: Effect of promoters. Catal. Today 2020. [CrossRef]

3. Gupta, P.; Paul, S. Solid acids: Green alternatives for acid catalysis. Catal. Today 2014, 236, 153-170. [CrossRef]

4. Abedin, M.A.; Kanitkar, S.; Bhattar, S.; Spivey, J.J. Sulfated hafnia as a support for Mo oxide: A novel catalyst for methane dehydroaromatization. Catal. Today 2020, 343, 8-17. [CrossRef] 
5. Kanitkar, S.; Abedin, M.A.; Bhattar, S.; Spivey, J.J. Methane dehydroaromatization over molybdenum supported on sulfated zirconia catalysts. Appl. Catal. A Gen. 2019, 575, 25-37. [CrossRef]

6. Abedin, M.A.; Kanitkar, S.; Bhattar, S.; Spivey, J.J. Mo oxide supported on sulfated hafnia: Novel solid acid catalyst for direct activation of ethane \& propane. Appl. Catal. A Gen. 2020, 602, 117696. [CrossRef]

7. Ho, S.C.; Wu, M.M. Isobutylene Oligomerization Using Supported Acid Catalysts. Google Patents No. 5,326,920, 5 July 1994.

8. Ho, S.C.; Wu, M.M. Supported Acid Catalysts, Their Preparation and Use in Organic Compound Conversion. Google Patents No. 5,294,578, 15 May 1994.

9. Krahl, T.; Kemnitz, E. The very strong solid Lewis acids aluminium chlorofluoride (ACF) and bromofluoride (ABF)-Synthesis, structure, and Lewis acidity. J. Fluor. Chem. 2006, 127, 663-678. [CrossRef]

10. Aarset, K.; Shen, Q.; Thomassen, H.; Richardson, A.D.; Hedberg, K. Molecular Structure of the Aluminum Halides, Al2Cl6, AlCl3, Al2Br6, AlBr3, and AlI3, Obtained by Gas-Phase Electron-Diffraction and ab Initio Molecular Orbital Calculations. J. Phys. Chem. A 1999, 103, 1644-1652. [CrossRef]

11. Heldman, J.D. Aliphatic Friedel-Crafts Reactions. I. The Alkylation of Butanes by Methyl and Ethyl Bromide. J. Am. Chem. Soc. 1944, 66, 1791-1793. [CrossRef]

12. Crafts, J.M.; Friedel, C. Organic chemistry. J. Chem. Soc. 1877, 32, 725-791. [CrossRef]

13. Corma, A.; García, H. Lewis Acids: From Conventional Homogeneous to Green Homogeneous and Heterogeneous Catalysis. Chem. Rev. 2003, 103, 4307-4366. [CrossRef]

14. Glasebrook, A.L.; Phillips, N.E.; Lovell, W.G. The Action of Aluminum Halides on n-Pentane. J. Am. Chem. Soc. 1936, 58, 1944-1948. [CrossRef]

15. Grummitt, O.; Sensel, E.E.; Smith, W.R.; Burk, R.E.; Lankelma, H.P. The Action of Aluminum Bromide on Paraffin Hydrocarbons. I. n-Hexane and n-Heptane. J. Am. Chem. Soc. 1945, 67, 910-914. [CrossRef]

16. Burbage, J.J.; Garrett, A.B. Phase Rule Studies in Anhydrous Aluminum Bromide. J. Phys. Chem. 1952, 56, 730-733. [CrossRef]

17. Walker, D.G. The association equilibrium in the methyl bromide-Aluminum bromide system. estimated bonding strengths of aluminum bromide-addition molecules with methyl bromide, pentene and benzene. J. Phys. Chem. 1960, 64, 939-941. [CrossRef]

18. Brown, H.C.; Wallace, W.J. Addition Compounds of Aluminum Halides with Alkyl Halides1. J. Am. Chem. Soc. 1953, 75, 6279-6285. [CrossRef]

19. Osterwalder, N.; Stark, W.J. Direct Coupling of Bromine-Mediated Methane Activation and Carbon-Deposit Gasification. ChemPhysChem 2007, 8, 297-303. [CrossRef] [PubMed]

20. Liao, J.; Bao, L.; Wang, W.; Xie, Y.; Chang, J.; Bao, W.; Chang, L. Preparation of AlCl3/silica gel catalyst for simultaneously removing thiophene and olefins from coking benzene by inclosed grafting method. Fuel Process. Technol. 2014, 117, 38-43. [CrossRef]

21. Fuentes, G.A.; Boegel, J.V.; Gates, B.C. n-butane isomerization catalyzed by supported aluminum chloride. J. Catal. 1982, 78, 436-444. [CrossRef]

22. El Maatougui, A.; Azuaje, J.; Sotelo, E.; Caamaño, O.; Coelho, A. Silica-Supported Aluminum Chloride-Assisted Solution Phase Synthesis of Pyridazinone-Based Antiplatelet Agents. ACS Comb. Sci. 2010, 13, 7-12. [CrossRef]

23. Boroujeni, K.P.; Parvanak, K. Efficient and solvent-free synthesis of bis-indolylmethanes using silica gel supported aluminium chloride as a reusable catalyst. Chin. Chem. Lett. 2011, 22, 939-942. [CrossRef]

24. Cámera, R.; Rimada, R.; Romanelli, G.; Autino, J.C.; Vázquez, P. Silica-supported aluminum chloride as catalyst for the tetrahydropyranylation of thymol. Catal. Today 2008, 133-135, 822-827. [CrossRef]

25. Li, Z.; Ma, X.; Liu, J.; Feng, X.; Tian, G.; Zhu, A. Silica-supported aluminum chloride: A recyclable and reusable catalyst for one-pot three-component Mannich-type reactions. J. Mol. Catal. A Chem. 2007, 272, 132-135. [CrossRef]

26. Sage, V.; Clark, J.H.; Macquarrie, D.J. Cationic polymerization of styrene using mesoporous silica supported aluminum chloride. J. Mol. Catal. A Chem. 2003, 198, 349-358. [CrossRef]

27. Xu, T.; Kob, N.; Drago, R.S.; Nicholas, J.B.; Haw, J.F. A Solid Acid Catalyst at the Threshold of Superacid Strength: NMR, Calorimetry, and Density Functional Theory Studies of Silica-Supported Aluminum Chloride. J. Am. Chem. Soc. 1997, 119, 12231-12239. [CrossRef]

28. Zupp, L.R.; Campanella, V.L.; Rudzinski, D.M.; Beland, F.; Priefer, R. Microwave-assisted silica-supported aluminum chloride-catalyzed Friedel-Crafts alkylation. Tetrahedron Lett. 2012, 53, 5343-5346. [CrossRef] 
29. Kumar, R.; Kumar, A.; Khanna, A. Synthesis, characterization and kinetics of AlCl3 supported on silica superacid catalysts for the formation of linear alkylbenzenes. React. Kinet. Mech. Catal. 2012, 106, 141-155. [CrossRef]

30. Cai, T.; He, M.; Shi, X.; Wang, X.; Han, D.; Lü, L. A study on structural suitability of immobilized aluminum chloride catalyst for isobutene polymerization. Catal. Today 2001, 69, 291-296. [CrossRef]

31. Xu, M.; Arnold, A.; Buchholz, A.; Wang, W.; Hunger, M. Low-Temperature Modification of Mesoporous MCM-41 Material with Sublimated Aluminum Chloride in Vacuum. J. Phys. Chem. B 2002, 106, 12140-12143. [CrossRef]

32. Zhao, X.S.; Lu, M.G.Q.; Song, C. Immobilization of aluminum chloride on MCM-41 as a new catalyst system for liquid-phase isopropylation of naphthalene. J. Mol. Catal. A Chem. 2003, 191,67-74. [CrossRef]

33. Borujeni, K.P.; Massah, A.R. Synthesis and application of polystyrene supported aluminium triflate as a new polymeric Lewis acid catalyst. React. Funct. Polym. 2006, 66, 1126-1131. [CrossRef]

34. Dai, L.; Zhang, Y.; Dou, Q.; Wang, X.; Chen, Y. Chemo/regioselective Aza-Michael additions of amines to conjugate alkenes catalyzed by polystyrene-supported AlCl3. Tetrahedron 2013, 69, 1712-1716. [CrossRef]

35. Tamami, B.; Parvanak Borujeny, K. Chemoselective tetrahydropyranylation of alcohols and phenols using polystyrene supported aluminium chloride as a catalyst. Tetrahedron Lett. 2004, 45, 715-718. [CrossRef]

36. Dubé, D.; Royer, S.; Trong On, D.; Béland, F.; Kaliaguine, S. Aluminum chloride grafted mesoporous molecular sieves as alkylation catalysts. Microporous Mesoporous Mater. 2005, 79, 137-144. [CrossRef]

37. Drago, R.S.; Petrosius, S.C.; Chronister, C.W. Characterization and improvements in the synthesis of the novel solid superacid AlCl2(SG)n. Inorg. Chem. 1994, 33, 367-372. [CrossRef]

38. Abedin, M.A.; Kanitkar, S.; Bhattar, S.; Spivey, J.J. Promotional Effect of Cr in Sulfated Zirconia-Based Mo Catalyst for Methane Dehydroaromatization. Energy Technol. 2019, 1900555. [CrossRef]

39. Sato, S.; Maciel, G.E. Structures of aluminum chloride grafted on silica surface. J. Mol. Catal. A Chem. 1995, 101, 153-161. [CrossRef]

40. Drago, R.S.; Petrosius, S.C.; Kaufman, P.B. Alkylation, isomerization and cracking activity of a novel solid acid, AlCl2(SG)n. J. Mol. Catal. 1994, 89, 317-327. [CrossRef]

41. Krossing, I. Fluoride Ion Affinity. Available online: https://portal.uni-freiburg.de/molchem/research/lewisacids/fia (accessed on 20 June 2016).

42. Kanitkar, S.; Carter, J.H.; Hutchings, G.J.; Ding, K.; Spivey, J.J. Low Temperature Direct Conversion of Methane using a Solid Superacid. ChemCatChem 2018, 10, 5019-5024. [CrossRef]

43. De, F.R.J.; Donald, S.; Leverne, C.N. Promoter For Isomerization Reaction. Google Patents No. 2956097, 10 November 1960.

44. Byron, J.G.; Mcdonald, S.M.F. Aluminum Halide Recycle Isomerization Process. Google Patents No. 3,077,504, 12 February 1963.

45. Opitz, H.E.; Peake, J.S.; Nebergall, W.H. The Preparation of Monobromosilane and Organic Silyl Derivatives. J. Am. Chem. Soc. 1956, 78, 292-294. [CrossRef]

46. Drago, R.S.; Getty, E.E. Hydrocarbon Conversion and Polymerization Catalyst and Method of Making and Using Same. Google Patents No. 4,719,190, 12 January 1988.

47. Parry, E.P. An infrared study of pyridine adsorbed on acidic solids. Characterization of surface acidity. J. Catal. 1963, 2, 371-379. [CrossRef]

48. Topaloğlu Yazıc1, D.; Bilgiç, C. Determining the surface acidic properties of solid catalysts by amine titration using Hammett indicators and FTIR-pyridine adsorption methods. Surf. Interface Anal. 2010, 42, 959-962. [CrossRef]

49. Zhai, S.-R.; Wei, W.; Wu, D.; Sun, Y.-H. Synthesis, Characterization and Catalytic Activities of Mesoporous AlMSU-X with Wormhole-Like Framework Structure. Catal. Lett. 2003, 89, 261-267. [CrossRef]

50. Dapurkar, S.E.; Selvam, P. Mesoporous H-AlMCM-48: Highly efficient solid acid catalyst. Appl. Catal. A Gen. 2003, 254, 239-249. [CrossRef]

51. Dwyer, J. A Critical Evaluation of the Concepts of Bröunsted Acidity Related to Zeolites. In Studies in Surface Science and Catalysis; Grobet, P.J., Mortier, W.J., Vansant, E.F., Schulz-Ekloff, G., Eds.; Elsevier: Amsterdam, The Netherlands, 1988; Volume 37, pp. 333-354. 
52. Grünberg, B.; Emmler, T.; Gedat, E.; Shenderovich, I.; Findenegg, G.H.; Limbach, H.-H.; Buntkowsky, G. Hydrogen Bonding of Water Confined in Mesoporous Silica MCM-41 and SBA-15 Studied by 1H Solid-State NMR. Chem. Eur. J. 2004, 10, 5689-5696. [CrossRef] [PubMed]

53. Ben Shir, I.; Kababya, S.; Schmidt, A. Molecular Details of Amorphous Silica Surfaces Determine Binding Specificity to Small Amino Acids. J. Phys. Chem. C 2014, 118, 7901-7909. [CrossRef]

(C) 2020 by the authors. Licensee MDPI, Basel, Switzerland. This article is an open access article distributed under the terms and conditions of the Creative Commons Attribution (CC BY) license (http://creativecommons.org/licenses/by/4.0/). 